\title{
Thoughts on Accelerating the Development of FCEV Industry in Sichuan Province
}

\author{
Yun Cai ${ }^{1,2} *$, Mengnan Guo ${ }^{2}$, Zongling Huang ${ }^{2}$, Shengming Han ${ }^{2}$, Xue Luo ${ }^{2}$ \\ ${ }^{1}$ School of Automobile and Transportation, Xihua University, Chengdu 610039 China \\ ${ }^{2}$ Chengdu Automobile Industry Research Institute, Chengdu 610100 China \\ * e-mail: 29682131@qq.com
}

\begin{abstract}
FCEV was an important development direction of new energy vehicles in the future. This paper aimed to explore the development strategy of the hydrogen fuel cell vehicle industry in Sichuan Province. Based on the systematic analysis of the basic connotation of the hydrogen fuel cell automobile industry, this paper analyzes the hydrogen fuel cell automobile industry at home and abroad and in Sichuan Province by using the open data such as marklines, Chengdu automobile industry data bank and policy text. Combining with the advantages and basic conditions of developing hydrogen fuel cell vehicle industry in Sichuan Province, the paper puts forward nine development suggestions, in terms of policies, innovations and projects, for the development of hydrogen fuel cell vehicle industry in Sichuan Province.
\end{abstract}

Keywords-FCEV; Development trend; Industry status; Suggestions

\section{INTRODUCTION}

As a clean and efficient secondary energy source, hydrogen energy has rich sources, high conversion efficiency, no emission pollution during use, and has wide application potential in transportation, energy storage and household integrated energy systems[1]. With the increasingly strong development trend of new energy vehicles in recent years, FCEV as the "ultimate goal" of the development of new energy vehicles have attracted more and more attention. Demonstration operation and industrial promotion of FCEV are being carried out in Guangdong Yunfu, Shanghai and other places in China. At present, the automobile industry in Sichuan Province is in the critical period of transformation and upgrading. Through the layout of FCEV in advance, it is expected to cultivate future development advantages and promote the high-quality development of the automobile industry.

\section{OVER VIEW OF FUEL CELL VEHICLE INDUSTRY}

\section{A. Definition and classification of fuel cell}

Unlike ordinary battery energy storage applications, a fuel cell is an energy conversion device that converts energy through a reaction process. Because the reactants are supplied from the outside rather than the inside of the battery, they are called "fuel"[2]. According to the types of electrolytes, fuel

Fund projects: Chengdu Science and technology project (2019-RK0000025-ZF), Sichuan Science and technology support plan project (2016GZ0017), Sichuan University Key Laboratory Project of Automotive Engineering (sziji2014-072). Sichuan Science and Technology Program (2019JDR0076) cells can be divided into alkaline fuel cells, phosphoric acid fuel cells, molten carbonate fuel cells, proton exchange membrane fuel cells and solid oxide fuel cells[3].

At present, the classification of fuel cells mainly has the following four types:

The first category, according to the operating mechanism of the fuel cell, is divided into acidic fuel cells, alkaline fuel cells.

The second category, according to the type of electrolyte, is divided into alkaline fuel cells, phosphoric acid fuel cells, molten carbonate fuel cells, proton exchange membrane fuel cells, and solid oxide fuel cells.

The third category, according to the type of fuel, divided into hydrogen fuel cells, methanol fuel cells, ethanol fuel cells and methane fuel cells.

The fourth category, according to the working temperature, is divided into low temperature $\left(200^{\circ} \mathrm{C}\right)$, medium temperature $\left(200 \sim 750^{\circ} \mathrm{C}\right)$ and high temperature $\left(750^{\circ} \mathrm{C}\right)$.

At present, the most widely used fuel cell in the field of automobile is proton exchange membrane fuel cell which uses hydrogen as fuel.

\section{B. Definition of fuel cell vehicle}

According to the definition of "Technology Roadmap for Energy Saving and New Energy Vehicles": FCEV refers to vehicles that use hydrogen as an energy source to convert the chemical energy of hydrogen into electrical energy through a proton exchange membrane fuel cell. It includes a car that uses fossil fuels as fuel and uses hydrogen produced by onboard devices as an energy source.

\section{Composition of fuel cell vehicle industry chain}

From the aspect of the industrial chain, it is mainly composed of fuel cell system, fuel cell vehicle, hydrogen energy industry and infrastructure[4]. Among them, the fuel cell system, including electric reactor, hydrogen supply system, air inlet system, cooling system, filling system and control system, is the core of fuel cell industrial chain. From the perspective of industrial chain value distribution, fuel cell systems account for about $70 \%$ of the cost of fuel cell vehicles, occupying the high-end part of the entire industry value chain. Among them, fuel cell stacks account for about $66 \%$ of the cost of fuel cell systems, and the cost of complete vehicles. $40 \%$; 
synchronization and passenger vehicle products still have a large catch-up distance. $25 \%$ of overall vehicle costs. From the perspective of industry chain intersection, fuel vehicles and new energy vehicles, such as pure electric vehicles and fuel cell vehicles, can achieve common use in chassis, body (Interior) and other parts, but there are differences in power systems and electric control. Although pure electric vehicles and fuel cell vehicles belong to new energy vehicles, they still have essential differences. Pure electric vehicles are driven by the energy stored in the battery, which requires high-energy-density batteries. Fuel cell vehicles react chemically through hydrogen and oxygen. Converting to electrical energy drives requires a large amount of hydrogen production.

\section{DEVELOPMENT TREND OF DOMESTIC AND INTERNATIONAL FCEV INDUSTRY}

As an important strategic emerging industry, fuel cell vehicles are regarded as the core application scenarios of the hydrogen energy industry with the most application prospects, broad market space and rapid conversion. It is the technical commanding height for the future development of the automobile industry.

\section{A. The strong support of supportive policies is an important} source of power for promoting the development of the fuel cell vehicle industry

According to the theory of the industrial life cycle, the fuel cell automobile industry is in its infancy, and the government's supportive policies are the main push to realize its industrialization. From a global perspective, developed countries and regions such as the United States, Europe, Japan and South Korea have all raised the development of fuel cell vehicles to a national strategy, and actively conveyed the government's support attitude towards industrial development from strategic planning and design, basic scientific research, product-market subsidies, infrastructure construction and other aspects[5]. From the perspective of the domestic situation, China's support for the hydrogen energy industry started in 2001, which is one of the countries with earlier supportive policies. However, the "new era" of industry development was not really started until the technical route of fuel cell vehicles was determined in 2016.

\section{B. The rapid breakthrough of key technologies is the key} factor in determining the core competitiveness of the fuel cell vehicle industry

In recent years, major automobile companies in the world have made great technological breakthroughs in the field of fuel cell vehicles, and vehicle performance has reached the level of traditional vehicles. From a global perspective, fuel cell vehicles have basically met the needs of commercial demonstration, but there is still a gap with traditional vehicles in terms of durability. In terms of the domestic situation, great progress has been made in fuel cell system integration and production and manufacturing of key components, but it still lags behind the foreign advanced in durability, key materials and core components[6]. Hydrogen fuel cell commercial vehicle products basically achieve international

\section{Decreasing cost space is the key factor to enlarge the market scale of fuel cell vehicle industry}

Compared with traditional fuel vehicles, the high cost of purchasing FCEV is a common problem in the world; compared with lithium-ion battery vehicles, the cost of hydrogen fuel cell vehicle purchases will not have a price advantage by 2020. From the perspective of research and development costs, because the fuel cell has not yet achieved substantial mass production, its research and development costs are much higher than fuel vehicles and pure electric vehicles. From the perspective of production cost, the production cost of fuel cell vehicles is 1.9 times and 9.9 times higher than that of pure electric vehicles and fuel vehicles, respectively, regardless of the cost of automobile parts. From the perspective of the cost of use, the current cost of fuel cell vehicles is basically the same as that of pure electric vehicles, regardless of the degree of infrastructure improvement, which is only about one-third of that of fuel vehicles.

\section{The enrichment and improvement of infrastructure is the core area to promote the commercialization of fuel cell vehicle industry}

At present, the convenience of fuel cell vehicles is far lower than that of fuel vehicles and pure electric vehicles. The high cost of infrastructure construction such as hydrogenation station is an important factor restricting the improvement of fuel cell vehicle application scenarios.

\section{DEVELOPMENT FOUNDATION OF FUEL CELL VEHICLE INDUSTRY IN SICHUAN PROVINCE}

\section{A. Development status of fuel cell vehicle industry in Sichuan Province}

Sichuan has a good foundation and favorable conditions in the field of hydrogen energy and fuel cell automobile industry development. From the perspective of resource endowment, in 2017, the province's conventional natural gas reserves reached 12.07 trillion cubic meters, the proportion of natural gas in the primary energy consumption structure reached $12.6 \%$, and the installed capacity of hydropower reached 70 million kilowatts, accounting for $22.2 \%$ of the whole country, providing a longterm and stable resource guarantee for vigorously developing the hydrogen energy and fuel cell rail transit industry.

From the perspective of industrial basis, Sichuan hydrogen energy and fuel cell vehicles have entered the primary stage of industrialization, with more than 60 key leading enterprises such as Dongfang Electric, and more than 12 key enterprises gathering key links of industrial chain such as hydrogen production, hydrogen storage, hydrogen fuel cell, hydrogen fuel cell vehicle, hydrogenation station and hydrogenation equipment, covering R \& D and design of vehicle, fuel cell power system and key materials, integration of production, manufacturing, hydrogenation and application, etc., and preliminary construction of a relatively complete hydrogen fuel cell vehicle industry chain. In terms of hydrogen production, 
Sichuan Province has 4 key hydrogen production enterprises, including Sichuan Tianyi Technology Co., Ltd., Sichuan Asian Union Technology Co., Ltd., Chengdu West China Technology Co., Ltd. Design Institute, Southwest Chemical Research Institute, etc., but the number of enterprises is small, mainly engaged in methane cracking hydrogen production, water electrolysis hydrogen production and other industries, which can provide technical support for hydrogen production industry. In terms of hydrogen storage, Sichuan Province has three key hydrogen storage enterprises, i.e. Sinoma Technology (Chengdu), Dongfang Electric and Sichuan meissel, which have the manufacturing capacity of 100000 hydrogen storage bottles per year. However, due to the large-scale commercial application of fuel cell vehicles, the production capacity of hydrogen storage bottles has not been fully utilized. In terms of hydrogen fuel cell, only Dongfang Electric Co., Ltd. and Chengdu zhongkelai Energy Technology Co., Ltd. are two key enterprises in Sichuan Province, which are involved in fuel cell engine, control system, battery diaphragm and other fields. However, proton exchange membrane, catalyst and other raw materials mainly rely on imports, and many links of core parts manufacturing industry chain are missing. In terms of FCEV, Sichuan Province only has two complete hydrogen fuel cell vehicle enterprises, Shudu Bus Co., Ltd. and Zhongzhi Yike Chengdu Automobile Co., Ltd. (the company is located in Longquanyi District). In February 2018, the hydrogen fuel cell vehicle jointly developed by Shudu Bus Co., Ltd. and Dongfang Electric Co., Ltd. has full independent intellectual property rights and has been approved to enter the Ministry of industry and information technology of the People's Republic of China. The report recommended catalogue; Zhongzhi Yike Chengdu Automobile Co., Ltd. and Shudu Bus Co., Ltd. also released a new hydrogen fuel bus in May 2018. In terms of hydrogenation and hydrogenation equipment, Sichuan Province only has three key enterprises of Tsinghua Energy Internet Research Institute, Sinoma Science and Technology, Huaqi Houpu (the company is located in Longquanyi District), among which Huaqi Houpu belongs to The listed company has the independent research and development capability of hydrogenation equipment. It is the earliest company to design box-type armored hydrogenation equipment in the country. It has successively deployed hydrogen filling equipment in Shanghai, Wuhan, Zhengzhou and Zhangjiakou.

In terms of promotion and application, Chengdu and Liangshan Prefecture were selected as pilot areas to promote more than 10 demonstration hydrogen fuel cell buses with a total operating mileage of $87510 \mathrm{~km}$, further promoting the development of hydrogen energy industry chain.

\section{B. The development status of Chengdu fuel cell automobile industry}

At present, Chengdu continues to improve the industrial chain and cultivate leading enterprises around the two terminal areas of FCEV and light rail trains. In 2017, the city's hydrogen energy industry achieved an output value of about 30 billion yuan, with more than 50 hydrogen-related enterprises and scientific research institutes, including more than 40 enterprises above Designated Size and 7 listed enterprises. The large-scale enterprises include Dongfang Electric, Chengdu bus, Zhongzhi
Yike, etc.; the main products include FCEV, hydrogen production equipment, filling equipment, hydrogen storage bottles, etc.

\section{Development Status of Fuel Cell Vehicle Industry in Chengdu Economic Development Zone}

Chengdu Economic and Technological Development Zone is the focus of automobile industry in Sichuan Province. At present, there are only two key enterprises related to fuel cell vehicles in Chengdu Economic and Technological Development Zone. Among them, Zhongzhi Yike is mainly engaged in the research and development and production of hydrogen fuel cell buses, and Huaqi Houpu is mainly engaged in the research and development and manufacture of key components of hydrogenation equipment. From the main products, Zhongzhi Yike and Beijing Yihuatong jointly launched the 4th generation hydrogen fuel cell city bus; Huaqi Houpu is the earliest company to design box-type armored hydrogenation equipment in China, and has been in Shanghai, Wuhan, Hydrogen filling equipment is arranged in Zhengzhou and Zhangjiakou. From the perspective of innovation capability, Zhongzhi Yike is accelerating the establishment of a new energy automobile research institute and actively developing new energy vehicle products including FCEV. The 35MPa hydrogenation flowmeter developed by Huaqi Houpu successfully broke the monopoly of imported brands.

\section{Suggestions on the DeVelopment OF Fuel CeLL VEHICLE INDUSTRY IN SICHUAN PROVINCE}

In view of the fact that the current fuel cell vehicles are still in the initial stage of the industry, the realization of large-scale commercial applications is expected to be around 2030.At present, Sichuan Province is actively constructing hydrogen energy and hydrogen fuel cell vehicle industry ecosystem with Longquanyi District as the core and integrating innovation, R\&D, manufacturing and demonstration. Therefore, Sichuan Province should take Chengdu Economic and Technological Development Zone as the core carrier, give full play to the advantages of automobile industry, focus on the R \& D and manufacturing of FCEV and key parts, actively layout the industrial chain from fuel cell system, fuel cell vehicles to hydrogen energy infrastructure, accelerate the building of domestic leading and internationally renowned industrial clusters, and drive the hydrogen industry and hydrogen fuel cell vehicle industry in Sichuan Province to achieve national leading and running.

\section{A. Taking policy as the sail and lead the industry to set sail}

First, strengthen organizational leadership. Establish a leading group for the development of fuel cell vehicle industry, study, makes decisions and deploy major plans, policies and work arrangements for the development of fuel cell vehicle industry, and timely coordinate and solve major problems in the development of the industry. The second is to increase policy support. Accelerate the research and development of the hydrogen fuel cell vehicle industry development plan and related support policies, and support the establishment of major industrial investment projects, the promotion and application of FCEV, and the construction of hydrogenation infrastructure. 
The third is to increase capital investment. In view of the fact that fuel cell vehicles have not yet formed commercial operation and large capital demand, the province, city and district jointly set up a special fund for hydrogen fuel cell vehicle industry development with a scale of not less than 1 billion yuan, and the existing fuel cell vehicles[7]. The company provides financial support for technology introduction, collaborative innovation, talent exchange and equity cooperation, and encourages existing auto companies to transform into fuel cell vehicles.

\section{B. Taking innovation as the rudder and step on the wave of Industrial Development}

The first is to set up a special project for technological innovation. Established a major scientific and technological project for FCEV of not less than 200 million yuan, integrated materials such as fuel cell stacks, catalysts, proton exchange membranes, carbon paper (gas diffusion layers), and fuel cell power system integration and control. Major research and development projects are supported. The second is to introduce innovative research and development results. Actively carry out cooperation between universities, colleges, enterprises and local governments, and actively carry out technical cooperation in key areas by building a number of technological innovation platforms, innovation research and development centers, production university research joint laboratories, etc., focusing on the advantageous disciplines of Tsinghua University, Tongji University, Wuhan University of technology and other universities. The third is to gather high-end talents in the industry. Docking the team of Tsinghua University Ouyang Minggao academician, Tsinghua University Li Jianqiu team, Dalian Institute of Chemical Physics Shao Zhigang of the Chinese Academy of Sciences, Wuhan University of Technology Mu Shichun team and other domestic high-end talents in FCEV, through the establishment of the chief scientist system to support local enterprises The establishment of strategic partnerships between university institutes, scientific research institutions and high-end talent teams will promote the transformation of high-end talent teams and innovative projects in the field of FCEV at home and abroad, and prioritize the inclusion of high-end talent teams in local high-end talents.

\section{Taking the project as the oar to build the industrial power engine}

The first is to carry out business investment. Accurately focus on the key links of the industrial chain such as fuel electric reactor, fuel cell system (engine), fuel vehicle integration, draw the "two diagrams and one table" of FCEV, and accelerate the introduction of a number of key core projects with core technologies to fill the gap in the industrial chain.. The second is to cultivate leading enterprises. Formulate a key enterprise cultivation plan, and focus on supporting a group of high-tech, competitive, and well-developed FCEV to grow into "specialized and special" enterprises and "little giants" enterprises. The third is to carry out demonstration operations. Adhere to the market-oriented way to promote industrial development, accelerate the construction of hydrogen fuel cell bus demonstration line, clear demonstration site selection, vehicle product procurement standards, vehicle purchase quantity and price, operation mode and cost and hydrogen station configuration and hydrogen use In terms of price and other issues, we strive to make the fuel cell "run-up."

\section{SUMMARY}

FCEV is a direction for future development. Sichuan fuel cell vehicle industry has a certain comparative advantage in China. Through analysis, three measures can be taken to speed up the development of Sichuan hydrogen fuel cell vehicle industry. One is to inject the start-up source for the industry through leading organization, policy support and capital guidance. The other is to provide innovation power for the industry through setting up special projects, transforming achievements and gathering talents. The third is to strengthen the industrial development foundation through project introduction, cultivation of leading enterprises and demonstration operation, promote the development of fuel cell automobile industry through multiple channels, and strive to make Sichuan Province occupy a place in the country.

\section{REFERENCES}

[1] Tian Shunhua. Construction of hydrogen society and popularization of fuel cell vehicles in Japan [J]. Petroleum and petrochemical green low carbon. 2016 (01): 31(In Chinese)

[2] Liu Haili, song Lijun, Liang Xin. Technical status and development direction of hydrogen fuel cell for vehicles [J]. Shanghai energy conservation, 2019 (08): 674-678.(In Chinese)

[3] He Jintao, Zheng Chuanbi. Analysis of the development trend of FCEV [J]. Heavy vehicles, 2019 (04): 24-26. (In Chinese)

[4] Yang Zibin. Development status and industrialization of FCEV in China [J]. Automotive practical technology, 2019 (16): 31-33. (In Chinese)

[5] Lin Chen. How can hydrogen fuel cells seize the bus market [n]. China Petroleum News, October 11, 2018 (004). (In Chinese)

[6] Wu Donglai. Analysis on the development of hydrogen fuel cell vehicle industry chain $[\mathrm{J}]$. Vehicle and driving maintenance (maintenance version). 2018 (09): 112-113(In Chinese)

[7] Wang Jia, Yao Zhanhui, Fang Haifeng, Liu Bin. A study on the policy system of China's fuel cell vehicles in the era of post-subsidy [J]. Automotive digest. 2019 (04): 52-57(In Chinese) 